Jurnal Fokus Manajemen Bisnis
Universitas
Ahmad Dahlan $\begin{gathered}\text { Jolume 11, Nomor 2, September 2021, Halaman 230-243 } \\ \text { https://doi.org/10.12928//fokus.v11i2.4651 } \\ \text { http://journal2.uad.ac.id/index.php/fokus }\end{gathered}$

\title{
PENGARUH SUASANA TOKO, KUALITAS PELAYANAN, KEPERCAYAAN, DAN PERSEPSI HARGA TERHADAP MINAT BELI ULANG
}

\author{
Monita Nugrahaeni' ${ }^{1}$, Ahmad Guspul2,, , Hermawan ${ }^{3}$ \\ Universitas Sains Al-Quran \\ agoespoel@yahoo.com \\ *Correspondent Author
}

Article History

Received 2021-08-10

Revised 2021-08-13

Accepted 2021-08-13

\section{Keywords}

Store Atmosphere;

Service Quality;

Price Perception;

Trust;

Repurchase Intention
This study aims to investigate the effect of store atmosphere, service quality, price perception, and trust on the repurchase intention of Ayam Geprek Susan in Wadaslintang. The sampling method of this study was the non-probability sampling by using the accidental sampling technique to 100 consumers. The data then being analyzed statistically by using multiple linear regression analysis, validity test, reliability test, and t-test. The result of the study shows that store atmosphere, service quality, price perception, and trust have a positive effect on consumer repurchase intention.

This is an open-access article under the CC-BY-SA license.

\section{Pendahuluan}

Berkembangnya teknologi mengakibatkan perubahan terhadap kehidupan masyarakat. Masyarakat menjadi lebih mudah dan cepat dalam mendapatkan referensi atau informasi. Sifat masyarakat yang tidak ingin ketinggalan tren menjadi pemicu berkembangnya sektor bisnis di segala aspek. Salah satu bisnis yang sedang mengalami perkembangan adalah bisnis kuliner (Harfania, 2018). Bisnis makanan atau dalam bidang food and beverages menjadi salah satu bisnis yang banyak diminati oleh masyarakat, karena selain menghasilkan keuntungan yang tinggi, makanan juga menjadi kebutuhan pokok bagi setiap orang. Jadi dimanapun dan kapanpun masyarakat akan membutuhkan makanan sebagai sumber pokok kehidupan (Ayodya, 2014).

Terbuka luasnya pasar serta peluang usaha yang semakin lebar menimbulkan berbagai macam alternatif pilihan produk yang dapat diberikan kepada konsumen dan pada akhirnya menimbulkan berbagai ekspektasi konsumen untuk memenuhi sesuatu yang diinginkannya. Kondisi ini menuntut perusahaan untuk bisa memberikan kepuasan pada konsumennya. Hal ini agar pelaku bisnis dapat mempertahankan bisnisnya secara berkesinambungan dengan perusahaan lain yang memiliki bidang bisnis yang sama (Milzan dkk., 2016). Maraknya bisnis kuliner yang sudah semakin ketat menjadi ancaman sekaligus motivasi bagi para pelaku usaha. Mereka dituntut untuk lebih mempertahankan produknya agar mampu bersaing serta perusahaan mampu memberi kepuasan konsumen dan mengenali karakteristik konsumen untuk melakukan pembelian ulang.

Salah satu bisnis kuliner yang juga merasakan ketatnya persaingan adalah Ayam Geprek Susan di Wadaslintang. Ayam Geprek Susan merupakan salah satu tempat makan cepat saji yang menyediakan ayam geprek sebagai menu andalannya. Selain itu, Ayam Geprek 
Susan merupakan rumah makan ayam geprek pertama yang berada di Wadaslintang sejak tahun 2017. Faktor yang mendorong sang pemilik untuk membuka usaha Ayam Geprek Susan dikarenakan pada waktu itu masih belum ada usaha kuliner ayam geprek di Wadaslintang. Menurut pemilik outlet, Ayam Geprek Susan mengalami pasang surut penjualan, akan tetapi selama 3 tahun terakhir ini Ayam Geprek Susan mengalami peningkatan yang signifikan karena adanya minat beli ulang konsumen yang berpengaruh besar terhadap tingkat penjualan.

Minat beli ulang konsumen sangatlah penting bagi perusahaan yang ingin memperpanjang kelangsungan hidup usahanya serta menuai keberhasilan usahanya dalam bentuk keuntungan jangka panjang. Hal tersebut dikarenakan mempertahankan pelanggan yang ada umumnya akan lebih menguntungkan dibandingkan dengan pergantian pelanggan karena biaya untuk menarik pelanggan baru bisa lima kali lipat dari biaya mempertahankan seorang pelanggan yang sudah ada (Kotler \& Keller, 2012). Lebih lanjut Kotler \& Keller (2012) mengartikan bahwa minat adalah sesuatu yang bersifat pribadi dan berhubungan dengan sikap. Individu yang berminat terhadap suatu objek akan mempunyai kekuatan atau dorongan untuk melakukan serangkaian tingkah laku untuk mendekati atau mendapatkan objek tersebut (Kotler \& Keller, 2012).

Faktor yang mempengaruhi minat beli ulang salah satunya adalah mengubah suasana toko agar lebih menarik. Mowen \& Minor (2012) mengatakan bahwa suasana toko merupakan unsur penting yang harus dimiliki toko. Penciptaan suasana yang menyenangkan, menarik, serta bisa membuat konsumen merasa nyaman ketika berada di dalam toko merupakan salah satu cara agar bisa menarik konsumen untuk melakukan tindakan pembelian (Levy \& Weitz, 2012). Suasana toko merupakan suatu bagian dari suasana dan tata letak suatu toko yang sangat penting dalam menarik calon konsumen. Desain toko harus memberi stimuli yang dapat menarik pengunjung agar dapat memutuskan toko mana yang akan dikunjungi. Suasana toko merupakan salah satu elemen bauran pemasaran ritel yang terkait dalam hal penciptaan suasana belanja. Suasana toko merupakan kunci dalam menarik dan membuat konsumen terkesan dengan pengalaman berbelanja di dalam gerai (Coley \& Burgess, 2003). Suasana toko hendaknya dibuat dan ditata sedemikian rupa dengan tujuan untuk meningkatkan kunjungan pelanggan sehingga pada akhirnya berimbas pada peningkatan penjualan dan membangun citra positif suatu toko (Ma'ruf, 2005). Lingkungan fisik atau suasana toko terbukti dapat mempengaruhi keputusan pembelian konsumen lebih kuat dibanding produk yang ditawarkan (Hersanti \& Ratnawati, 2012).

Banat \& Wandebori (2012) menyatakan bahwa suasana toko yang meliputi dimensi kebersihan, musik, aroma, suhu, pencahayaan, warna, dan tampilan memberi pengaruh yang signifikan terhadap minat beli ulang. Bisa dipahami bahwa terdapat hubungan antara suasana toko dan niat beli ulang, karena suasana toko dapat mempengaruhi niat beli ulang konsumen (Meldarianda dkk., 2010). Suasana toko yang didesain secara tepat dan baik akan dapat mendorong konsumen untuk pasti membeli barang di toko tersebut (Sofyan dkk., 2013).

Faktor selanjutnya adalah kualitas pelayanan. Kualitas layanan adalah model yang menggambarkan kondisi pelanggan dalam membentuk harapan akan layanan dari pengalaman masa lalu, promosi dari mulut ke mulut, dan iklan dengan membandingkan pelayanan yang mereka harapkan dengan apa yang mereka terima atau rasakan (Kotler \& Keller, 2012). Menurut Tjiptono (2015) kualitas pelayanan dapat diartikan sebagai upaya pemenuhan kebutuhan dan keinginan konsumen serta ketepatan penyampaiannya dalam mengimbangi harapan konsumen, salah satu yang mempengaruhi tingkat loyalitas konsumen adalah kualitas pelayanan.

Lewis \& Booms (2012) mendefinisikan kualitas pelayanan secara sederhana yaitu ukuran seberapa bagus tingkat layanan yang diberikan mampu sesuai dengan ekspektasi pelanggan. Artinya, kualitas pelayanan ditentukan oleh kemampuan perusahaan atau lembaga tertentu untuk memenuhi kebutuhan yang sesuai dengan apa yang diharapkan atau 
diinginkan berdasarkan kebutuhan pelanggan atau pengunjung. Kualitas pelayanan dapat diketahui dengan cara membandingkan persepsi para konsumen atas pelayanan yang diterima dengan pelayanan yang sesungguhnya konsumen harapkan terhadap atribut-atribut pelayanan suatu perusahaan (Zaithaml et al., 1996).

Selanjutnya, faktor penting lainnya yang berpengaruh terhadap minat beli ulang adalah sebuah kepercayaan. Kepercayaan adalah semua pengetahuan yang dimiliki oleh konsumen dan semua kesimpulan yang dibuat konsumen tentang objek atribut dan manfaatnya (Mowen \& Minor, 2012). Kepercayaan didefinisikan sebagai salah satu dari dimensi hubungan bisnis yang menentukan tingkat dimana masing-masing pihak merasa dapat bergantung pada integritas janji yang ditawarkan oleh pihak lain (Kolsaker \& Payne, 2002). Kepercayaan seseorang kepada toko menimbulkan keinginan seseorang untuk mengabarkan kepada kerabatnya untuk berbelanja di toko tersebut. Kepercayaan konsumen sebagai persepsi akan keterhandalan dari sudut pandang konsumen yang didasarkan pada pengalaman atau lebih pada urutan transaksi atau interaksi yang dicirikan oleh terpenuhinya harapan akan kinerja produk dan kepuasan (Ferrinadewi, 2005).

Faktor berikutnya yang dapat mempengaruhi minat beli konsumen adalah persepsi harga. Zeithaml et al. (2013) menyatakan bahwa persepsi harga adalah pengorbanan pelanggan untuk mendapatkan produk atau jasa yang diinginkan. Menurut Peter \& Olson (2016) persepsi harga adalah menyangkut bagaimana informasi harga dipahami oleh pelanggan dan dibuat bermakna bagi mereka. Pernyataan tersebut dapat disimpulkan sebagai suatu proses penilaian seorang terhadap harga pada produk dan jasa yang diketahui melalui masukan informasi, kejadian, pengalaman pembelian serta hal lainnya. Kemudian persepsi tersebut disimpulkan pada sebuah pertimbangan apakah harga dirasa sesuai manfaat, cocok, terjangkau, sesuai harapan atau sebaliknya yang akan membantu dan mempengaruhi minat seseorang melakukan pembelian, keputusan pembelian, dan minat beli ulang (Achmad, 2017).

\section{Review Literatur dan Hipotesis}

\subsection{Landasan Teori}

\subsubsection{Minat Beli Ulang}

Menurut Kotler et al. (2014) minat beli timbul setelah adanya proses evaluasi alternatif. Dalam proses evaluasi, seseorang akan membuat suatu rangkaian pilihan mengenai produk yang hendak dibeli atas dasar merek maupun minat. Menurut Thamrin \& Tantri (2012) minat beli ulang merupakan minat pembelian yang didasarkan atas pengalaman pembelian yang telah dilakukan di masa lalu. Minat beli ulang yang tinggi mencerminkan tingkat kepuasan yang tinggi dari konsumen ketika memutuskan untuk mengadopsi suatu produk. Dengan demikian, menurut definisi disimpulkan bawha minta beli ulang merupakan perilaku dimana konsumen memiliki rasa ingin memiliki, menggunakan, dan mengonsumsi suatu produk yang sama lebih dari satu kali pembelian.

\subsubsection{Suasana Toko}

Sumaryanti dkk. (2011) mengatakan atmosphere mengacu kepada karakteristik fisik yang memproyeksikan citra dan gambaran konsumen akan toko. Atmosphere dari suatu toko dapat mempengaruhi kenyamanan belanja konsumen, seperti berkeliling, keinginan untuk berkomunikasi dengan pegawai, kecenderungan untuk membuangbuang waktu dan uang dari yang direncanakan, dan kemungkinan untuk menjadi pelanggan tetap (Berman \& Evans, 2011). Dari definisi di atas, dapat disimpulkan bahwa suasana toko yang nyaman memicu penilaian yang baik untuk konsumen dan daya tarik untuk melakukan pembelian kembali. Selain itu, suasana toko juga dapat menjadi daya tarik oleh para konsumen karena masing-masing toko pasti memiliki ciri 
khas tersendiri. Penataan lampu dan pemilihan cat yang mewah serta aesthatic juga diperlukan karena itu merupakan salah satu daya tarik yang kuat.

\subsubsection{Kualitas Pelayanan}

Menurut Kotler \& Keller (2012) pelayanan adalah setiap tindakan atau kegiatan yang dapat ditawarkan oleh suatu pihak kepada pihak lain, yang pada dasarnya tidak berwujud dan tidak mengakibatkan kepemilikan apapun. Lewis \& Booms (2012) mendefinisikan kualitas jasa sebagai ukuran seberapa bagus tingkat layanan yang diberikan mampu sesuai dengan ekspektasi pelanggan. Berdasarkan definisi ini, kualitas layanan ditentukan oleh kemampuan-kemampuan perusahaan memenuhi keinginan dan kebutuhan pelanggan sesuai dengan ekspektasi pelanggan. Apabila kualitas jasa yang diterima oleh konsumen lebih baik atau sama dengan konsumen bayangkan, maka konsumen cenderung akan mencobanya kembali dan membeli ulang produk tersebut.

\subsubsection{Persepsi Harga}

Malik (2012) mendefinisikan persepsi harga sebagai suatu proses dimana pelanggan menerjemahkan nilai harga dan atribut ke barang ataupun jasa yang diinginkannya. Lovelock \& Wirtz (2011) mengemukakan bahwa penetapan harga bertujuan untuk menghasilkan laba, menutup biaya, menciptakan permintaan, dan mengembangkan pengguna. Sebelum memasarkan produknya di pasar, perusahaan perlu menetapkan harga produk tersebut. Menurut Swastha (2012) harga merupakan sejumlah uang dengan ditambahkan beberapa barang memungkinkan yang dibutuhkan untuk menambah kombinasi dari barang dan pelayanannya. Secara historis, harga sudah menjadi faktor utama yang mempengaruhi pilihan pembeli. Dalam beberapa dekade terakhir, faktor-faktor nonharga semakin penting. Namun, harga tetap menjadi salah satu elemen terpenting yang menentukan pangsa pasar dan profitabilitas perusahaan (Kotler \& Keller, 2012).

\subsubsection{Kepercayaan}

Dalam membangun suatu kepercayaan, seseorang harus memiliki integritas yang tinggi yang menjadi ukuran bahwa seseorang atau suatu kelompok melakukan segala sesuatunya dengan konsisten, kompeten, jujur, adil dan bertanggung jawab (Sahanggamu dkk., 2015). Kepercayaan seseorang kepada toko, menimbulkan seseorang untuk mengabarkan kepada kerabatnya untuk berbelanja di toko tersebut. Menurut Kotler \& Keller (2012) kepercayaan adalah kesediaan perusahaan untuk bergantung pada mitra bisnis. Kepercayaan tergantung pada beberapa faktor antar pribadi dan antar organisasi seperti kompetensi, integritas, kejujuran, dan kebaikan hati.

\subsection{Hipotesis}

\subsubsection{Pengaruh Positif Suasana Toko terhadap Minat Beli Ulang}

Suasana toko (store atmosphere) memiliki peran penting bagi setiap bisnis dan bisa mempengaruhi perasaan atau mood dari para konsumen yang berkunjung ke tokoh sehingga mempengaruhi minat untuk membeli. Suasana toko berperan sebagai pencipta suasana yang nyaman sesuai dengan keinginan konsumen dan membuat konsumen ingin berlama-lama berada di dalam toko dan secara tidak langsung merangsang konsumen untuk melakukan pembelian (Julianti dkk., 2011). Banat \& Wandebori (2013) menyatakan bahwa suasana toko yang meliputi dimensi kebersihan, musik, aroma, suhu, pencahayaan, warna, dan tampilan memberi pengaruh yang signifikan antara minat beli ulang. Pendapat ini didukung oleh pendapat dari Sutisna \& 
Pawitra (2010) yang mengatakan bahwa store atmosphere dapat mempengaruhi keadaan yang positif. Keadaan emosional yang positif akan membuat dua perasaan senang dan membangkitkan keinginan. Hal tersebut juga didukung hasil penelitian dari Achmad (2017), Prabowo (2018), dan Hendrayani (2019) yang menunjukkan hasil bahwa suasana toko membawa dampak positif pada tingkat pembelian ulang dari konsumen. Berdasarkan uraian di atas, maka dapat dirumuskan hipotesis sebagai berikut:

\section{$\mathrm{H}_{1}$ : Suasana Toko Berpengaruh Positif terhadap Minat Beli Ulang}

\subsubsection{Pengaruh Positif Kualitas Pelayanan terhadap Minat Beli Ulang}

Lovelock \& Wirtz (2011) mengatakan bahwa jika kinerja layanan jasa mendekati atau melebihi tingkat layanan yang diinginkan (desired service level), akan membuat rasa senang di benak pelanggan dan pelanggan akan sangat dimungkinkan berminat untuk melakukan pembelian ulang. Dari penelitian terdahulu Chendradewi \& Khasanah (2016) serta Devi dkk. (2020) menyatakan bahwa kualitas pelayanan memiliki pengaruh yang positif dan signifikan terhadap minat beli ulang. Apabila kualitas pelayanan baik, maka pelanggan akan merasa puas dan minat beli ulang akan meningkat. Berdasarkan uraian di atas, maka dapat dirumuskan hipotesis sebagai berikut:

\section{$\mathrm{H}_{2}$ : Kualitas Pelayanan Berpengaruh Positif terhadap Minat Beli Ulang}

\subsubsection{Pengaruh Positif Kepercayaan terhadap Minat Beli Ulang}

Kepercayaan adalah suatu keyakinan antara satu pihak lainnya mengenai terhadap suatu hal. Kepercayaan pelanggan diartikan sebagai harapan pelanggan bahwa penyediaan jasa dapat dipercaya dan diandalkan untuk memenuhi janji terhadap konsumen (Siagian \& Cahyono, 2014). Penjelasan ini didukung oleh penelitian Chendradewi \& Khasanah (2016) serta Prabowo (2018) yang membuktikan bahwa kepercayaan berpengaruh positif pada minat beli ulang konsumen. Berdasarkan uraian di atas, maka dapat dirumuskan hipotesis sebagai berikut:

\section{$\mathrm{H}_{3}$ : Kepercayaan Berpengaruh Positif terhadap Minat Beli Ulang}

\subsubsection{Pengaruh Positif Persepsi Harga terhadap Minat Beli Ulang}

Hasil penelitian yang dilakukan oleh Aufa \& Kamal (2015), Chendradewi \& Khasanah (2016), serta Achmad (2017) membuktikan bahwa persepi harga berpengaruh terhadap minat beli ulang. Menurut Hariyanti (2011) bahwa harga yang sebanding dengan apa yang didapatkan tentu membuat konsumen tidak ragu untuk mengkonsumsi produk tersebut. Konsumen lebih memilih produk dengan harga yang bersaing namun mampu memenuhi harapan dari konsumen tentang sebuah produk (Heriyanti, 2011). Berdasarkan uraian di atas, maka dapat dirumuskan hipotesis sebagai berikut:

\section{$\mathrm{H}_{4}$ : Persepsi Harga Berpengaruh Positif terhadap Minat Beli Ulang}




\subsection{Model Penelitian}

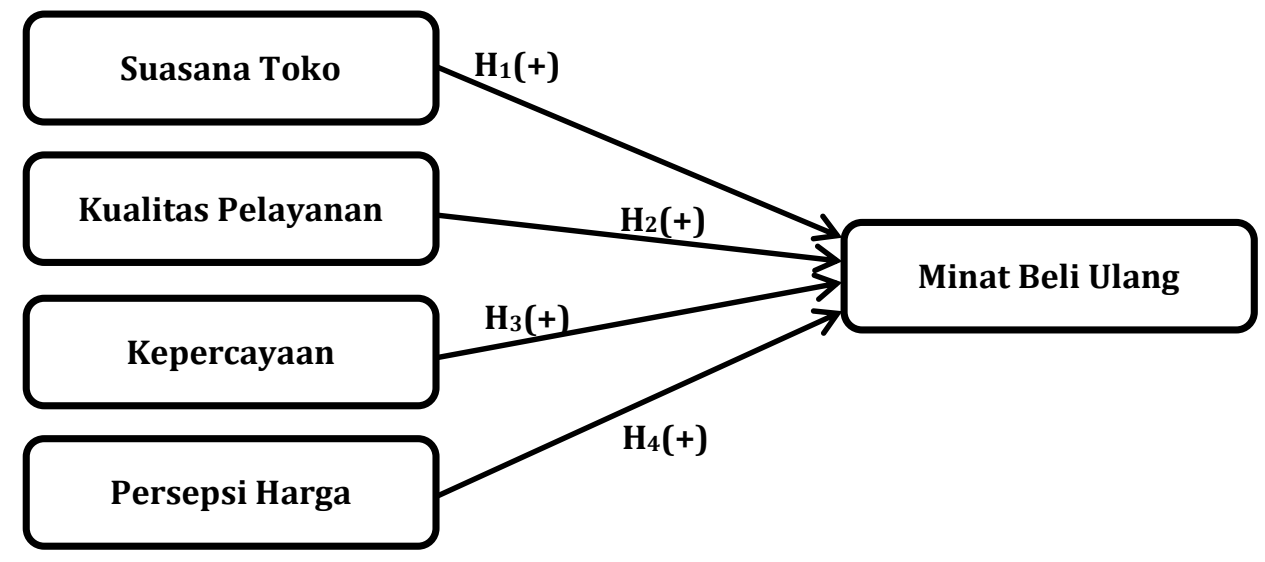

Gambar 1. Kerangka Penelitian

\section{Metode Penelitian}

\subsection{Populasi dan Sampel}

Menurut Sugiyono (2014) populasi adalah wilayah generalisasi yang terdiri atas objek atau subjek yang mempunyai kualitas dan karakteristik tertentu yang ditetapkan oleh peneliti untuk dipelajari dan kemudian ditarik kesimpulannya. Populasi dalam penelitian ini adalah seluruh Konsumen Ayam Geprek Susan di Wadaslintang. Lebih lanjut, Sugiyono (2014) mendefinisikan sampel adalah bagian dari jumlah dan karakteristik yang dimiliki oleh populasi tersebut. Dalam penelitian ini teknik pengambilan sampel menggunakan teknik nonprobalility sampling. Teknik nonprobability sampling yang digunakan penulis dalam penelitian ini yaitu dengan menggunakan teknik accidental sampling. Accidental sampling adalah teknik penentuan sampel berdasarkan kebetulan yaitu konsumen yang secara kebetulan atau insidental bertemu dengan peneliti dapat digunakan sebagai sampel, bila dipandang orang yang kebetulan ditemui itu cocok sebagai sumber data (Sugiyono, 2014).

Gay \& Diehl (1992) menyarankan bahwa ukuran sampel tergantung pada jumlah indikator yang digunakan dalam seluruh variabel. Jumlah sampel adalah sama dengan jumlah indikator dikalikan 5. Pada penelitian ini jumlah total keseluruhan indikator adalah 20 indikator, sehingga jumlah sampel minimal pada penelitian ini adalah sebanyak 100 orang responden. Penelitian komparatif ukuran sampai lebih dari 30 dan kurang dari 500 responden adalah tepat (Gay \& Diehl, 1992).

\subsection{Teknik Pengumpulan Data}

Menurut Creswell (2014) kuesioner merupakan teknik pengumpulan data dimana responden mengisi pertanyaan atau pernyataan kemudian setelah diisi dengan lengkap mengembalikan kepada peneliti. Kuesioner pada penelitian ini terdiri dari beberapa indikator variabel penelitian. Variabel suasana toko terdiri dari 4 indikator (Berman \& Evans, 2011), variabel kualitas pelayanan terdiri dari 5 indikator (Zeithaml et al., 1996), variabel kepercayaan terdiri dari 3 indikator (Mayer et al., 2010), variabel persepsi harga terdiri dari 4 indikator (Kotler \& Keller, 2012), dan variabel minat beli ulang terdiri dari 6 indikator (Ferdinand, 2014). Kuesioner dalam penelitian ini menggunakan pendekatan skala likert yaitu skala yang digunakan untuk mengukur sikap, pendapat, dan persepsi seseorang atau kelompok orang tentang fenomena sosial (Sugiyono, 2014). Angka 1 (satu) menunjukkan bahwa responden memberikan tanggapan yang bersifat negatif (sangat tidak setuju) terhadap indikator yang diajukan, sedangkan angka 5 (lima) menunjukkan tanggapan yang bersifat positif (sangat setuju). 


\subsection{Teknik Analisis Data}

\subsubsection{Uji Validitas}

Uji validitas digunakan untuk mengukur sah atau tidaknya suatu kuesioner (Ghozali, 2018). Ghozali (2018) mendefinisikan uji validitas sebagai alat untuk mengukur sah atau valid tidaknya suatu kuesioner. Suatu kuesioner dikatakan valid jika pertanyaan atau indikator pada kuesioner mampu untuk mengungkapkan sesuatu yang akan diukur oleh kuesioner tersebut. Pada penelitian ini uji validitas akan dilakukan dengan bantuan program SPSS for Windows 20.0. Untuk menentukan indikator valid atau tidak, perlu disesuaikan dengan nilai tabel product moment. Kriteria penilaian uji validitas adalah apabila $r$-hitung $>$ r-tabel, maka indikator kuesioner tersebut valid. Besarnya nilai r-tabel dalam penelitian ini adalah 0,195.

\subsubsection{Uji Reliabilitas}

Uji reliabilitas merupakan uji kehandalan yang bertujuan untuk membuktikan seberapa jauh suatu alat ukur dapat dipercaya. Kehandalan berkaitan dengan estimasi sejauhmana suatu alat ukur konsisten apabila pengukuran dilakukan berulang dan hasil pengukuran yang diperoleh relatif konsisten, maka alat ukur tersebut dianggap handal atau reliabel. Sebaliknya, bila suatu alat ukur digunakan berulang dan hasil pengukuran yang diperoleh tidak konsisten, maka alat ukur tersebut dianggap tidak reliabel. Dalam pengujian reliabilitas, dilakukan dengan membandingkan nilai cronbach's alpha dengan tingkat signifikansi sebesar 0,7. Suatu konstruk atau variabel dikatakan reliabel jika nilai cronbach's alpha $>0,7$ (Ghozali, 2018).

\subsubsection{Uji Regresi Linear Berganda}

Untuk menguji hubungan variabel dependen dengan variabel independen dalam penelitian ini akan digunakan model regresi linier berganda. Menurut Ghozali (2018) analisis regresi linier berganda merupakan persamaan regresi dengan menggunakan dua atau lebih variabel independen. Persamaan regresi dalam penelitian ini adalah:

Keterangan :

$$
Y=\alpha+\beta_{1} X_{1}+\beta_{2} X_{2}+\beta_{3} X_{3}+\beta_{4} X_{4}+e
$$

$\mathrm{Y}=$ Minat Beli Ulang

$\alpha=$ Konstanta

e = Standard Error

$\beta=$ Koefisien Variabel

$\mathrm{X}_{1}=$ Suasana Toko

$\mathrm{X}_{2}=$ Kualitas Pelayanan

$\mathrm{X}_{3}=$ Kepercayaan

$\mathrm{X}_{4}=$ Persepsi Harga

\subsubsection{Uji Hipotesis}

Pengujian secara parsial yaitu pengujian koefisien regresi secara parsial dengan menentukan formula statistik yang akan diuji. Uji parsial digunakan untuk membuktikan seberapa besar pengaruh secara parsial variabel independen terhadap variabel dependen dengan tingkat alpha sebesar 0,05 (Ghozali, 2018). Kriteria yang digunakan untuk menilai hipotesis adalah jika nilai t-hitung > t-tabel dan sig. hitung < 0.05 , maka hipotesis diterima, dan sebaliknya. Nilai t-tabel yang digunakan dalam penelitian ini adalah sebesar 1,98498. 
4. Hasil dan Pembahasan

\subsection{Hasil Uji Validitas}

Tabel 1. Hasil Uji Validitas

\begin{tabular}{|c|c|c|c|}
\hline Variabel & Indikator & R-Hitung & Keterangan \\
\hline \multirow[t]{4}{*}{ Suasana Toko } & ST 1 & 0,907 & Valid \\
\hline & ST 2 & 0,913 & Valid \\
\hline & ST 3 & 0,925 & Valid \\
\hline & ST 4 & 0,929 & Valid \\
\hline \multirow[t]{5}{*}{ Kepuasan Pelayanan } & KP 1 & 0,918 & Valid \\
\hline & KP 2 & 0,915 & Valid \\
\hline & KP 3 & 0,905 & Valid \\
\hline & KP 4 & 0,896 & Valid \\
\hline & KP 5 & 0,897 & Valid \\
\hline \multirow[t]{3}{*}{ Kepercayaan } & KC 1 & 0,879 & Valid \\
\hline & KC 2 & 0,877 & Valid \\
\hline & KC 3 & 0,870 & Valid \\
\hline \multirow[t]{4}{*}{ Persepsi Harga } & $\mathrm{PH} 1$ & 0,886 & Valid \\
\hline & $\mathrm{PH} 2$ & 0,838 & Valid \\
\hline & PH 3 & 0,882 & Valid \\
\hline & $\mathrm{PH} 4$ & 0,849 & Valid \\
\hline \multirow[t]{6}{*}{ Minat Beli Ulang } & MBU 1 & 0,769 & Valid \\
\hline & MBU 2 & 0,761 & Valid \\
\hline & MBU 3 & 0,685 & Valid \\
\hline & MBU 4 & 0,858 & Valid \\
\hline & MBU 5 & 0,865 & Valid \\
\hline & MBU 6 & 0,710 & Valid \\
\hline
\end{tabular}

Sumber: Data Diolah (2020)

Hasil uji validitas yang dapat dilihat pada tabel 1 menunjukkan nilai r-hitung yang lebih besar dari r-tabel $(0,195)$ dari setiap indikator variabel. Maka dari itu, seluruh indikator variabel suasana toko, kualitas pelayanan, kepercayaan, persepsi harga, dan minat beli ulang dapat dikatakan valid dan layak untuk diuji lebih lanjut.

\subsection{Hasil Uji Reliabilitas}

Tabel 2. Hasil Uji Reliabilitas

\begin{tabular}{c|c|c|}
\hline Variabel & Cronbach's Alpha & Keterangan \\
\hline Suasana Toko & 0,938 & Reliabel \\
Kualitas Pelayanan & 0,946 & Reliabel \\
Kepercayaan & 0,847 & Reliabel \\
Persepsi Harga & 0,887 & Reliabel \\
Minat Beli Ulang & 0,868 & Reliabel \\
\hline
\end{tabular}

Sumber: Data Diolah (2020)

Secara keseluruhan uji reliabilitas yang dilakukan dalam penelitian ini telah menunjukkan hasil yang memuaskan. Hal ini terlihat dari tabel 2 yang menunjukkan nilai cronbach's alpha lebih besar dari nilai batas cronbach's alpha 0,7. Maka dari itu, seluruh indikator pernyataan yang berkaitan dengan variabel suasana toko, kualitas pelayanan, kepercayaan, persepsi harga, dan minat beli ulang dapat dikatakan reliabel. 
4.3. Hasil Analisis Regresi Linear Berganda

Tabel 3. Hasil Analisis Regresi Linear Berganda

\begin{tabular}{|c|c|c|c|c|c|}
\hline Model & \multicolumn{2}{|l|}{ Unstandardized Coefficients } & $\begin{array}{c}\text { Standardized } \\
\text { Coefficients }\end{array}$ & Sig. \\
\cline { 2 - 4 } & B & Std. Error & Beta & & \\
\hline $\begin{array}{c}\text { (Constant) } \\
\text { Suasana Toko }\end{array}$ & 2,264 & 2,105 & 1,075 & 0,285 \\
Kualitas & 0,281 & 0,096 & 0,226 & 2,914 & 0,004 \\
Pelayanan & 0,330 & 0,085 & 0,302 & 3,907 & 0,000 \\
Kepercayaan & 0,458 & 0,136 & 0,293 & 3,380 & 0,001 \\
Persepsi & 0,283 & 0,128 & 0,189 & 2,213 & 0,029 \\
Harga & & & & \\
\hline
\end{tabular}

Sumber: Data Diolah (2020)

Berdasarkan hasil yang ditunjukkan tabel 3 dapat diperoleh persamaan regresi sebagai berikut:

$$
Y=2,264+0,281 X_{1}+0,330 X_{2}+0,458 X_{3}+0,283 X_{4}+2,105 e
$$

Persamaan regresi tersebut mempunyai arti sebagai berikut:

1. Konstanta sebesar 2,264 yang artinya apabila suasana toko, kualitas pelayanan, kepercayaan, dan persepsi harga sama dengan 0 , maka minat beli ulang akan bernilai 2,264 .

2. Koefisien regresi variabel suasana toko sebesar 0,281. Artinya, jika suasana toko meningkat satu satuan, maka minat beli ulang akan naik sebesar 0,281.

3. Koefisien regresi variabel kualitas pelayanan sebesar 0,330. Artinya, jika kualitas pelayanan meningkat satu satuan, maka minat beli ulang akan naik sebesar 0,330.

4. Koefisien regresi variabel kepercayaan sebesar 0,458. Artinya, jika kepercayaan meningkat satu satuan, maka minat beli ulang akan naik sebesar 0,458.

5. Koefisien regresi variabel persepsi harga sebesar 0,283. Artinya, jika persepsi harga meningkat satu satuan, maka minat beli ulang akan naik sebesar 0,283.

\subsection{Hasil Uji Hipotesis}

\begin{tabular}{|c|c|c|c|c|c|}
\hline \multirow[t]{2}{*}{ Model } & \multicolumn{2}{|c|}{ Unstandardized Coefficients } & \multirow{2}{*}{$\begin{array}{c}\begin{array}{c}\text { Standardized } \\
\text { Coefficients }\end{array} \\
\text { Beta } \\
\end{array}$} & \multirow[t]{2}{*}{$\mathbf{t}$} & \multirow[t]{2}{*}{ Sig. } \\
\hline & B & Std. Error & & & \\
\hline (Constant) & 2,264 & 2,105 & & 1,075 & 0,285 \\
\hline Suasana Toko & 0,281 & 0,096 & 0,226 & 2,914 & 0,004 \\
\hline Kualitas & 0,330 & 0,085 & 0,302 & 3,907 & 0,000 \\
\hline Pelayanan & & & & & \\
\hline Kepercayaan & 0,458 & 0,136 & 0,293 & 3,380 & 0,001 \\
\hline $\begin{array}{c}\text { Persepsi } \\
\text { Harga }\end{array}$ & 0,283 & 0,128 & 0,189 & 2,213 & 0,029 \\
\hline
\end{tabular}

Sumber: Data Diolah (2020)

Berdasarkan tabel 4 dapat dilihat hasil uji hipotesis sebagai berikut:

1. Pengaruh Positif Suasana Toko terhadap Minat Beli Ulang

Suasana toko memiliki nilai koefisien 0,281, nilai signifikansi $0,004<0,05$, dan nilai t-hitung 2,914 > nilai t-tabel 1,98498. Jadi, dapat disimpulkan bahwa hipotesis pertama yang mengatakan suasana toko berpengaruh positif terhadap minat beli ulang diterima.

2. Pengaruh Kualitas Pelayanan terhadap Minat Beli Ulang

Kualitas pelayanan memiliki nilai koefisien 0,330, nilai signifikansi $0,000<0,05$, dan nilai t-hitung 3,907 > nilai t-tabel 1,98498. Jadi, dapat disimpulkan bahwa hipotesis 
kedua yang mengatakan kualitas pelayanan berpengaruh positif terhadap minat beli ulang diterima.

3. Pengaruh Kepercayaan terhadap Minat Beli Ulang

Kepercayaan memiliki nilai koefisien 0,458, nilai signifikansi 0,001 $<0,05$, dan nilai t-hitung 3,380 > nilai t-tabel 1,98498. Jadi, dapat disimpulkan bahwa hipotesis ketiga yang mengatakan kepercayaan berpengaruh positif terhadap minat beli ulang diterima.

4. Pengaruh Persepsi Harga terhadap Minat Beli Ulang

Persepsi harga memiliki nilai koefisien 0,283, nilai signifikansi $0,029<0,05$, dan nilai t-hitung 2,213 > nilai t-tabel 1,98498. Jadi, dapat disimpulkan bahwa hipotesis keempat yang mengatakan persepsi harga berpengaruh positif terhadap minat beli ulang diterima.

\subsection{Pembahasan}

\subsubsection{Pengaruh Positif Suasana Toko terhadap Minat Beli Ulang}

Hipotesis pertama yang mengatakan bahwa suasana toko berpengaruh positif terhadap minat beli ulang diterima. Berdasarkan dari uji hipotesis diperoleh nilai koefisien 0,281, nilai t-hitung 2,914 > nilai t-tabel 1,98498, dan nilai signifikansi 0,004< 0,05 , sehingga dapat disimpulkan bahwa suasana toko berpengaruh positif terhadap minat beli ulang.

Hal ini menunjukkan bahwa semakin tinggi suasana dalam toko tersebut maka akan meningkatkan minat beli ulang. Hasil penelitian ini sejalan dengan penelitian sebelumnya yang dilakukan penelitian Achmad (2017), Prabowo (2018), dan Hendrayani (2019) bahwa suasana toko berpengaruh terhadap minat beli ulang. Penelitian ini membuktikan bahwa suasana toko yang nyaman memicu penilaian yang baik dari konsumen dan meningkatkan daya tarik untuk melakukan pembelian ulang. Suasana toko berperan sebagai pencipta suasana yang nyaman sesuai dengan keinginan konsumen dan membuat konsumen ingin berlama-lama berada di dalam toko dan secara tidak langsung merangsang konsumen untuk melakukan pembelian ulang. Suasana toko yang meliputi dimensi kebersihan, musik, aroma, suhu, pencahayaan, warna, dan tampilan dapat mempengaruhi minat beli ulang.

\subsubsection{Pengaruh Positif Kualitas Pelayanan terhadap Minat Beli Ulang}

Hipotesis kedua yang mengatakan bahwa kualitas pelayanan berpengaruh positif terhadap minat beli ulang diterima. Berdasarkan dari uji hipotesis yang diperoleh nilai koefisien 0,330, nilai t-hitung 3,907 > nilai t-tabel 1,98498, dan nilai signifikansi 0,000< 0,05 , sehingga dapat disimpulkan bahwa kualitas pelayanan berpengaruh positif terhadap minat beli ulang.

Hal ini menunjukkan bahwa semakin baik kualitas pelayanan toko, maka akan meningkatkan minat beli ulang. Hasil penelitian ini sejalan dengan penelitian sebelumnya yang dilakukan Chendradewi \& Khasanah (2016) serta Devi dkk. (2020) yang menyatakan bahwa kualitas pelayanan mempunyai pengaruh positif terhadap minat beli ulang. Penelitian ini membuktikan bahwa dengan adanya kualitas pelayanan yang baik akan berdampak pada kepuasan pelanggan. Kualitas pelayanan sebagai usaha untuk mewujudkan kenyamanan terhadap konsumen agar konsumen merasa mempunyai nilai yang lebih dari yang diharapkan. Pelayanan diberikan kepada para konsumen seperti kemampuan karyawan untuk berkomunikasi dengan pelanggan dan usaha untuk memahami keinginan dan kebutuhan pelanggan sehingga akan meningkatkan minat beli ulang. 


\subsubsection{Pengaruh Positif Kepercayaan terhadap Minat Beli Ulang}

Hipotesis ketiga yang mengatakan bahwa kepercayaan berpengaruh positif terhadap minat beli ulang diterima. Berdasarkan dari uji hipotesis diperoleh nilai koefisien 0,458, nilai t-hitung 3,380 > nilai t-tabel 1,98498, dan nilai signifikansi 0,001< 0,05 , sehingga dapat disimpulkan bahwa kepercayaan berpengaruh positif terhadap minat beli ulang.

Hal ini menunjukkan bahwa semakin tinggi kepercayaan konsumen pada toko tersebut, maka akan meningkatkan minat beli ulang. Hasil penelitian ini sejalan dengan penelitian sebelumnya yang dilakukan Chendradewi \& Khasanah (2016) serta Prabowo (2018) bahwa kepercayaan berpengaruh positif terhadap minat beli ulang. Penelitian ini membuktikan bahwa dengan adanya kepercayaan yang baik yang dimiliki konsumen akan berdampak tingkat keinginan untuk melakukan pembelian ulang suatu produk atau jasa. Kepercayaan sangatlah mempengaruhi konsumen dalam menentukan minat beli ulang karena kepercayaan konsumen adalah pondasi utama dari suatu bisnis. Keinginan konsumen untuk membeli suatu produk didasarkan pada kepercayaan yang berkaitan dengan tindakan membeli atau menggunakan produk tersebut. Dari kepercayaan konsumen terhadap sebuah barang atau produk, maka akan menimbulkan minat beli di masa yang akan datang.

\subsubsection{Pengaruh Positif Persepsi Harga terhadap Minat Beli Ulang}

Hipotesis keempat yang mengatakan bahwa persepsi harga berpengaruh positif terhadap minat beli ulang diterima. Berdasarkan dari uji hipotesis diperoleh nilai koefisien 0,283, nilai t-hitung 2,213 > nilai t-tabel 1,98498, dan nilai signifikansi 0,029< 0,05 , sehingga dapat disimpulkan bahwa persepsi harga berpengaruh positif terhadap minat beli ulang.

Hal ini menunjukkan bahwa semakin tinggi persepsi harga yang baik pada toko tersebut, maka akan meningkatkan minat beli ulang. Hasil penelitian ini sejalan dengan penelitian sebelumnya dari Aufa \& Kamal (2015), Chendradewi \& Khasanah (2016) serta Achmad (2017) yang menyatakan bahwa persepsi harga mempunyai pengaruh positif terhadap minat beli ulang. Penelitian ini membuktikan bahwa perlu adanya persepsi harga yang tepat terhadap sebuah produk agar konsumen tertarik untuk membeli, karena dalam persaingan usaha persepsi harga yang ditawarkan oleh pesaing bisa lebih rendah dengan kualitas yang sama atau bahkan dengan kualitas lebih baik. Dalam menentukan persepsi harga sebuah produk atau jasa yang dijual, perusahaan dituntut untuk memperhatikan konsumen dan para pesaingnya. Harga yang sebanding dengan apa yang didapatkan tentu membuat konsumen tidak ragu untuk mengkonsumsi produk tersebut. Konsumen lebih memilih produk dengan harga yang bersaing namun mampu memenuhi harapan tentang sebuah produk, sehingga dapat meningkatkan pembelian ulang.

\section{Kesimpulan dan Saran}

\subsection{Kesimpulan}

Berdasarkan hasil penelitian yang telah diuraikan sebelumnya, maka dapat disimpulkan: pertama, suasana toko mempunyai pengaruh positif terhadap minat beli ulang. Artinya, semakin baik suasana toko, maka akan menciptakan rasa nyaman dan pada akhirnya dapat mempengaruhi minat seorang konsumen untuk melakukan pembelian ulang. Kedua, kualitas pelayanan mempunyai pengaruh positif terhadap minat beli ulang. Artinya, dengan kualitas pelayanan yang diberikan secara maksimal, maka konsumen akan merasa puas dan dapat mempengaruhi minat seorang konsumen untuk melakukan pembelian ulang. Ketiga, kepercayaan mempunyai pengaruh positif terhadap minat beli ulang. Artinya, apabila kepercayaan seorang konsumen terhadap suatu toko meningkat 
atas kualitas pelayanan dan suasana toko, maka akan mempengaruhi minat konsumen tersebut untuk melakukan pembelian ulang. Keempat, persepsi harga mempunyai pengaruh positif terhadap minat beli ulang. Artinya, semakin baik persepsi harga yang dimiliki konsumen terhadap harga yang diberikan oleh suatu toko, maka akan mempengaruhi minat konsumen tersebut untuk melakukan pembelian ulang.

\subsection{Saran}

Berdasarkan hasil penelitian, saran yang dapat diberikan antara lain Ayam Geprek Susan harus membuat suasana toko lebih menarik dengan cara selalu mengatur tatanan letak toko, memberikan hiasan toko, atau memutar lagu yang dapat memberikan kesan nyaman bagi konsumen. Selanjutnya, Ayam Geprek Susan harus melakukan evaluasi sejauh mana harga yang ditawarkan apakah sesuai dengan pangsa pasar dan dapat terjangkau oleh konsumen sehingga dapat bersaing dengan kompetitif. Berikutnya, Ayam Geprek Susan harus lebih inovatif lagi dalam menyediakan kualitas layanan, menjaga kepercayaan yang baik dengan para konsumen agar mereka merasa puas dengan pelayanannya dan menimbulkan keinginan untuk melakukan pembelian ulang. Terakhir, peneliti berikutnya dalam menilai faktor yang mempengaruhi minat pembelian ulang dapat menggunakan variabel selain yang sudah digunakan dalam penelitian ini agar dapat memberikan hasil yang lebih maksimal dan menambah wawasan seputar ilmu pemasaran.

\section{Daftar Pustaka}

Achmad, F. (2017). Pengaruh Persepsi Harga dan Kualitas Layanan terhadap Minat Pembelian Ulang (Survei pada Konsumen Go-ride di Kota Surabaya). Doctoral dissertation, Universitas Brawijaya.

Aufa, Z. D., \& Kamal, M. (2015). Analisis Pengaruh Ragam Menu, Persepsi Harga, Lokasi dan Kualitas Layanan terhadap Minat Beli Ulang pada Soto Sedep Banyumanik Cabang Ambarawa. Doctoral dissertation, Fakultas Ekonomika dan Bisnis.

Ayodya, W. (2014). 110 Solusi Jadi Pengusaha yang Berkah. Elex Media Komputindo.

Banat, A., \& Wandebori, H. S. T. (2012). Store Design and Store Atmosphere Effect on Customer Sales Per Visit Economics. Management and Behavioral Sciences, 84-89.

Berman, B., \& Evans, J. R. (2011). Retailing Management. Pearson.

Chendradewi, R., \& Khasanah, I. (2016). Analisis Pengaruh Persepsi Harga, Kepercayaan Pelanggan, Kualitas Pelayanan, dan Kualitas Produk terhadap Keputusan Pembelian (Studi Pada Waroeng Steak \& Shake Semarang Cabang Kelud). Diponegoro Journal of Management, 5(4), 267-278.

Coley, A., \& Burgess, B. (2003). Gender Differences in Cognitive and Affective Impulse Buying. Journal of Fashion Marketing and Management: An International Journal.

Creswell, J. W. (2014). Research Design: Qualitative, Quantitative, and Mixed. Methods Approaches (4th ed.). SAGE Publication.

Devi, I. P., Teja, I. G. N. A. E., \& Rihayana, I. G. (2020). Pengaruh Persepsi Harga, Kualitas Makanan, dan Kualitas Pelayanan terhadap Niat Beli Di Warung Dekade. Values, 1(2), 129-138.

Ferdinand, A. (2014). Metode Penelitian Manajemen. Badan Penerbit Universitas Diponegoro.

Ferrinadewi, E. (2005). Atribut Produk yang Dipertimbangkan dalam Pembelian Kosmetik dan Pengaruhnya pada Kepuasan Konsumen di Surabaya. Jurnal Manajemen dan Kewirausahaan, 7(2), 139-151.

Gay, L.R., \& Diehl, P.L. (1992). Research Methods for Business and Management. MacMillan Publishing Company. 
Ghozali, I. (2018). Aplikasi Analisis Multivariate dengan Program IBM SPSS 25. Badan Penerbit Universitas Diponegoro.

Harfania, F. (2018). Pengaruh Promosi Penjualan, Experiential Marketing, Kualitas Produk, dan Kualitas Pelayanan terhadap Minat Beli Ulang (Studi Kasus pada Restoran Ayam Geprek Sa'i Yogyakarta). Jurnal Manajemen Bisnis Indonesia (JMBI), 7(6), 581-591.

Hariyanti, A. D. (2011). Analisis Pengaruh Kualitas Produk, Persepsi Harga, dan Kualitas Layanan terhadap Minat Beli Ulang Produk Perlengkapan Kunci Di PT. Kenari Djaja Prima Semarang. Jurnal Sains Pemasaran Indonesia, 10(1), 47-87.

Hendrayani, H. (2019). Pengaruh Suasana Toko (Store Atmosphere) terhadap Minat Beli Konsumen di Planet Surf Mall Panakukang Makassar. Economix, 7(1).

Hersanti, N. J., \& Ratnawati, K. (2012). Pengaruh Atmosfer terhadap Kepuasan dan Niatan Perilaku Konsumen di Toko "Oen" Kota Malang. Jurnal Aplikasi Manajemen, 10(4), 772-780.

Julianti, N. L., Nuridja, I. M., \& Meitriana, M. A. (2014). Pengaruh Suasana Toko (Store Atmosphere) terhadap Minat Beli Konsumen pada Toserba Nusa Permai di Kecamatan Nusa Penida Tahun 2014. Jurnal pendidikan ekonomi Undiksha, 4(1).

Kolsaker, A., \& Payne, C. (2002). Engendering Trust in E-Commerce: A Study of Gender-Based Concerns. Marketing Intelligence \& Planning.

Kotler, P., \& Keller, K. L. (2012). Marketing Management Edition 14th. Pearson Education.

Kotler, P., Bowen, J. T., \& Makens, J. C. (2014). Marketing for Hospitality and Tourism. Pearson Prentice Hall.

Levy, M., \& Weitz, B. A. (2012). Retailing Management Information Center. McGraw-Hill.

Lewis, R. C., \& Booms, B. H. (2012). The Marketing Aspects of Service Quality. Chicago.

Lovelock, C., \& Wirtz, J. (2011). Service Marketing. Pearson.

Ma'ruf, H. (2005). Pemasaran Ritel. PT. Gramedia Pustaka Utama.

Malik, A. (2012). Pembentukan Karakter Peserta Didik Melalui Nilai-Nilai Budaya Reog Di Kabupaten Madiun. Jurnal Pendidikan, 232-237.

Mayer, D. M., Kuenzi, M., \& Greenbaum, R. L. (2010). Examining The Link between Ethical Leadership and Employee Misconduct: The Mediating Role of Ethical Climate. Journal of Business Ethics, 95(1), 7-16.

Meldarianda, R., Lisan, H., \& Kristen, U. (2010). Pengaruh Store Atmosphere terhadap Minat Beli Konsumen pada Resort Café Atmosphere Bandung. Jurnal Bisnis dan Ekonomi (JBE), 17(2), 97-108.

Milzan, F., Kridalukmana, R., \& Windasari, I. P. (2016). Sistem Informasi Geografis Tour and Travel Berbasis Android Di Kabupaten Tegal. Jurnal Teknologi dan Sistem Komputer, 4(2), 276-281.

Mowen, J. C., \& Minor, M. (2012). Perilaku Konsumen. Terjemahan Dwi Kartika Yahya. Erlangga.

Sofyan, I. L., Pradhanawati, A., \& Nugraha, H. S. (2013). Pengaruh Fasilitas dan Kualitas Pelayanan terhadap Loyalitas Melalui Kepuasan Konsumen sebagai Variabel Intervening pada Star Clean Car Wash Semarang. Jurnal Ilmu Administrasi Bisnis.

Peter, P. J., \& Olson J. C. (2016). Perilaku Konsumen dan Strategi Pemasaran. Edisi Terjemahan. Salemba Empat.

Prabowo, S. A. (2018). Pengaruh Suasana Toko, Kualitas Pelayanan, Kepercayaan, dan Persepsi Harga Terhadap Minat Beli Ulang Konsumen Mirota Kampus Godean. Jurnal Ekobis Dewantara, 1(7), 115-126.

Pramana, I. G. Y., \& Rastini, N. M. (2016). Pengaruh Kualitas Pelayanan Terhadap Kepercayaan 
Nasabah dan Loyalitas Nasabah Bank Mandiri Cabang Veteran Denpasar Bali. E-Jurnal Manajemen Universitas Udayana, 5(1).

Sahanggamu, S., Mananeke, L., \& Sepang, J. (2015). Analisis Kualitas Layanan, Servicescape, dan Kepercayaan terhadap Kepuasan Nasabah pada PT. Bank Sinarmas Bitung. Jurnal EMBA: Jurnal Riset Ekonomi, Manajemen, Bisnis dan Akuntansi, 3(1).

Siagian, H., \& Cahyono, E. (2014). Analisis Website Quality, Trust, dan Loyalty Pelanggan Online Shop. Jurnal Manajemen Pemasaran, 8(2), 55-61.

Sugiyono. (2014). Metode Penelitian Bisnis Pendekatan Kuantitatif, Kualitatif, dan R\&D. Alfabeta.

Sumaryanti, U., Supriyanto, A., \& Purnama, B. (2011). Karakterisasi Optik dan Listrik Larutan Klorofil Spirulina sp sebagai Dye Sensitized Solar Cell. Jurnal Material dan Energi Indonesia, 1(03), 141-147.

Sutisna \& Pawitra, T. (2010). Perilaku Konsumen dan Komunikasi Pemasaran. PT. Remaja Rosdakarya.

Swastha, B. (2012). Manajemen Penjualan. BPFE-Yogyakarta.

Thamrin, A., \& Tantri, F. (2012). Manajemen Pemasaran. PT. Rajagrafindo Persada.

Tjiptono, F. (2015). Strategi Pemasaran. Andi Offset.

Zeithaml, V.A., Bitner, M.J., \& Gremler, D.D. (2013). Service Marketing: Integrating Customer Focus Across the Firm. Mc.Graw-Hill.

Zeithaml, V. A., Berry, L. L., \& Parasuraman, A. (1996). The Behavioral Consequences of Service Quality. Journal of Marketing, 60(2), 31-46. 